\title{
Sweetpotato cultivars differ in efficiency of wound healing
}

Quirien van Oirschot

Natural Resources Institute, University of Greenwich,

Central Avenue, Chatham,

Kent ME4 4TB, United Kingdom.

Tel: +441634883564

Fax: +44 1634883567

e-mail: q.vanoirschot@gre.ac.uk,

Research area:

Environmental Stress and Adaptation 


\section{Sweetpotato cultivars diffier in efficiency of wound healing}

Quirien Elfrida Antoinette van Oirschot ${ }^{1}$, Deborah Rees ${ }^{1}$, Julia Aked ${ }^{2}$ and Agnes

Kihurani $^{3}$

1. Natural Resources Institute, University of Greenwich, Central Avenue, Chatham, Kent ME4 4TB, United Kingdom.

2. Cranfield University at Silsoe, Silsoe, Beds MK45 4DT, United Kingdom

3. National Agricultural Research Laboratories, Kenyan Agricultural Research Institute, Nairobi, Kenya 
This publication is an output from a research project funded by the United Kingdom Department for International Development (DFID) for the benefit of developing countries. The views expressed are not necessarily those of DFID [R6507: Crop PostHarvest Research Programme]. The research was carried out in collaboration with the International Potato Center (CIP), National Agricultural Research Laboratories at KARI, Nairobi, Kenya, the Tanzanian National Root and Tuber Crops Programme, Ukiriguru, Tanzania and USDA-ARS, USA.

Corresponding author:

Quirien van Oirschot, Natural Resources Institute, University of Greenwich, Central Avenue, Chatham, Kent ME4 4TB, United Kingdom.

Tel: +44 16348835 64, Fax: +441634 8835 67, e-mail: q.vanoirschot@gre.ac.uk, 


\section{Abstract}

This paper presents a study on the wound healing processes in sweetpotatoes (Ipomoea batatas Lam.) when exposed to tropical conditions typical for marketing (RH $50 \%$ to $73 \%, \mathrm{~T} 25^{\circ} \mathrm{C}$ to $30^{\circ} \mathrm{C}$ ). The physiological processes during healing are revisited. Under sub-optimal humidities $(65 \% \pm 10)$ the depth of the lignified layer i.e. the thickness of the desiccated cell layers is affected by both cultivar and humidity. Some cultivars consistently failed to produce a lignified layer and for others the layer is often not continuous. The continuity of the lignified layer is more important for effectiveness of wound healing than the actual thickness. A method for assessing efficiency of wound healing based on assessing the continuity of lignified layers was developed, and called the lignification index. Wound healing efficiency as measured by the lignification index was found to be a major factor for the shelf-life of sweetpotato cultivars. Lignification of wounds correlates with reduced rate of weight loss and reduced susceptibility to microbial infection. A high dry matter content in cultivars correlated with a low lignification index. This relationship was consistent for 5 trials, including 34 cultivars. 


\section{Introduction}

The ability of plant tissues to heal wounds is vital to prevent excessive water loss and pathogen invasion. This is exploited to improve storability of root crops after harvest by a process termed curing, in which they are placed in an environment to promote healing of wounds incurred during harvesting and handling. Sweetpotato (Ipomoea batatas Lam) is similar in this respect to other root and tuber crops such as potato (Solanum tuberosum), cassava (Manihot esculenta Crantz) and yam ( Dioscorea spp.) (Lulai and Orr, 1995, Rickard, 1985, Passam et al., 1976).

Descriptions of the process of wound healing in sweetpotato date from the 1920s when Weimer and Harter (1921) described how moisture and temperature affect the wound periderm formation and the efficiency of the wound cork in preventing infection. Artschwager and Starret (1931) distinguished three stages of healing; 1) desiccation of several cell layers of parenchyma; 2) thickening of cell walls (suberization or lignification) in underlying cell layers; 3) formation of the wound periderm.

The desiccation of cell layers in which the cells on the surface dry out and die is the first response after wounding. Under sub-optimal healing conditions this layer of desiccated cells may be thicker, which is unfavourable for shelf life of the roots as it favours the growth of pathogens (Nielsen and Johnson, 1974). The effect of cultivar on the thickness of the desiccated layer in sweetpotatoes has not been reported.

Lignification is probably the most crucial step in the wound healing process. Cell walls below the desiccated cell layers become thickened, although there is some 
uncertainty about the exact chemical nature of this thickening (Walter and Schadel, 1982; 1983). Artschwager and Starett (1931) reported that the thickened cell layers absorb crystal violet which indicates suberisation. Later, McClure (1960) found that these cells have a much stronger affinity for a saturated solution of phloroglucinol in $18 \% \mathrm{HCl}$, which indicates a lignin like structure. With mass spectroscopy, Walter and Schadel (1983) confirmed that the polymeric compounds in these cells had the chemical properties of lignin. Once this lignified layer is formed a new wound periderm will form underneath, even if the roots are removed from curing conditions (Walter and Schadel, 1982; Morris and Mann, 1955), although it develops more quickly under curing conditions.

The wound periderm consists of cell layers, stacked in a similar way to the native periderm. The thickness of the wound periderm may vary according to the cultivar. Morris and Mann (1955) found thicknesses varying from 4 to 10 layers while Walter and Schadel (1983) and St Amand and Randle (1991) reported thicknesses between 5 and 6.7 layers. Walter and Schadel (1982) considered a wound periderm needed to be approximately 4.2 cell layers thick to be effective against water loss and pathogen invasion.

Wounds in sweetpotatoes heal most efficiently when the roots are exposed to temperatures of $28-30^{\circ} \mathrm{C}$ and a relative humidity $(\mathrm{RH})$ greater than $85 \%$ (Kushman and Wright, 1969). Although curing is practised commercially in temperate areas, in the tropics it is often assumed that it takes place naturally (Collins and Walter 1985; Woolfe 1992) and is not actively practised. Jenkins (1982) reported that artificial curing under tropical conditions in Bangladesh did not reduce weight losses. 
However, the high levels of weight loss and very short shelf-life often seen in the tropics put into doubt whether wound healing takes place.

In East Africa sweetpotatoes have a shelf-life of only one to two weeks during marketing (Rees et al., 2001). In storage trials carried out under simulated marketing conditions in Tanzania, it was found that rates of root weight loss and rotting both varied considerably among cultivars. Weight loss ranged from $8 \%$ to $30 \%$ over two weeks in one trial $\left(\mathrm{T}=24.2 \pm 1.4^{\circ} \mathrm{C}, \mathrm{RH}=56.1 \pm 5.7 \%\right)$ (Rees et al., 2002). There was an association between cultivar root water loss and rotting, and it was suggested that under marketing conditions rotting is controlled primarily by desiccation. Further, a correlation was noted between cultivar susceptibility to weight loss, and both root dry matter (positive correlation) and root monosaccharide levels (negative correlation). The work reported in this paper was conducted to determine whether this was due to the characteristics of root wound-healing. Some variability has been found among sweetpotato cultivars in the rate of wound healing (Strider and McCombs, 1958; St Amand and Randle, 1991). However, very little is known about the wound healing characteristics of African germplasm, how this relates to shelf-life and also how the process is affected by sub-optimal humidities. A better understanding of the wound healing process under sub-optimal conditions may contribute to efforts to extend shelf life of root crops by improved handling and cultivar selection. Further, the findings would be of general interest, as such conditions are more typical of the environments under which plant tissue healing would normally occur.

This paper first investigates the physiological characteristics of the wound healing process in African cultivars when exposed to conditions sub-optimal for curing. A 
rapid method to assess wound healing efficiency is described that can be used by sweetpotato breeding programmes in developing countries where sophisticated equipment is not available. This method was validated to establish the relationship between wound healing characteristics of sweetpotato cultivars and their keeping qualities, including water loss, susceptibility to micro-organisms and shelf-life. 


\section{Results and discussion}

\section{Physiology of wound healing at sub-optimal humidities}

Relative humidity (RH) affects the pattern of wound healing in sweetpotato roots, but the effects vary by cultivar. Figure 1 shows the cross section of roots of eight sweetpotato cultivars after wounding and subsequent storage for three days at 97, 65 and 58\% RH. Roots that were kept at lower humidity after wounding show sunken wound surfaces, presumably due to desiccation. The response of roots to the lower humidities appears to be cultivar dependent, with tissue shrinkage more pronounced for the cultivars SPK 004, Kemb 10, KSP 20 and Caplina. For these cultivars a thick desiccated crust formed which was difficult to cut. Less shrinkage and much thinner desiccated crusts were observed for the cultivars Zapallo, Salyboro, Yan Shu 1 and Julian. Figure 2A,B shows micrographs of sections through wounds healed at $71 \%$ RH for two contrasting cultivars; KSP20 and Zapallo. Both cultivars show surface layers of desiccated cells which are flattened and appear white due to the concentration of starch granules as the cells lose water. This has been described previously for sweetpotato by Artschwager and Starett (1931) and for yam (Dioscorea spp.) by Passam et al. (1976). Consistent with the observations above, the micrographs show that Zapallo has a much thinner desiccated layer than KSP20.

Lignified layers started to develop below the desiccated layer from two days after wounding for most cultivars, although after one day for some roots of some cultivars, notably Yan Shu 1 and KSP20. Lignification started at the periphery of the wound under the periderm, and subsequently developed towards the centre of the wound

(Figure 2C). For some cultivars a continuous lignin layer never developed, but the 
layer remained patchy/discontinuous (Figure 2B), or even absent (Figure 2D) at the centre of the wound.

More detailed studies were carried out on five of the eight cultivars. The number of lignified cell layers observed by microscopy increased for five days after wounding and healing at $82 \%$ RH (Table 3a). The mean number of lignified cell layers for the 5 cultivars were significantly different and varied between 0.47 and 3.65 after 4 days and 1.75 and 3.36 after 5 days. This is a thinner layer then reported for curing at high humidity by Walter and Schadel (1983) who found on average 4.3 layers of suberised cells after 5 to 7 days.

Given that it is not possible to differentiate cells in the desiccated layer, a better indication of the thickness of both desiccated and lignified layers could be obtained by measurement using a graticule (Table $3 b$ ). Table $3 b$ shows data obtained for roots that had been stored for 1 and 6 weeks after harvest. For the lignified layer highly significant differences among cultivars were observed for 2, 4, 6 and 10 days of healing. Results were less clear for the desiccated cell layers, but cultivar differences were significant after 4 days and highly significant after 10 days. An effect of storage time was only apparent after 10 days of healing, at which time SPK004 and Kemb10 had much thinner lignified layers, and thicker desiccated layers, while the other three cultivars showed no change. The cultivars SPK004 and Kemb10 had the thinnest lignified layers throughout healing with some roots completely failing to lignify. Yan Shu 1 and Zapallo had the thickest lignified layers. The results confirmed the findings of Walter and Schadel (1983) that after 4 days lignification is complete, but disagreed with the results of St Amand and Randle (1991), who described an almost linear 
increase in the number of lignified cell layers from 0 to 7 layers between 3 and 12 days after wounding (at $\mathrm{RH} 85 \%$ T $29^{\circ} \mathrm{C}$ ).

\section{Continuity and depth of the lignified layer}

Average thickness of lignified layer gives no indication of the completeness of the layer. As mentioned above, for some wounds lignification occurred in a patchy pattern, with 5 to 6 lignified layers in some places, but no lignification in others (Figure 2B), while some wounds completely failed to produce lignin (Figure 2D). Failure to lignify was observed in 30 out of 46 roots of SPK004 and 26 out of 42 roots for Kemb10.

The thickness of the desiccated cell layer, and hence the depth of the lignified layer (Table 3) appears to be related to the efficiency of the healing process. Absence of a lignified layer usually coincided with a very thick desiccated layer and development of a hard wound surface. In these cases, the desiccated layer stained bright red with safranin-fast green, indicating the presence of phenolics, consistent with disruption of lignin synthesis. On the other hand, in those cultivars with efficient lignin synthesis, the desiccated layer tended to be thin and the lignified cell layers close to the surface (e.g. Zapallo, Figure 2A). Strider and McCombs (1958) observed such a pattern when comparing roots cured at different humidities. Thus, they reported a thick desiccated layer (17 cell layers) where the roots were kept at $21^{\circ} \mathrm{C}$ and $60 \% \mathrm{RH}$, compared to a depth of 4 to 6 layers where roots were healed at an RH of $95 \%$. These authors did not compare different cultivars. 


\section{Lignification index (L.I.)}

A range of methods to measure progress of wound healing have been reported in the literature. Cell layers may be counted using microscopy (as above and Strider and McCombs, 1958). Walter and Schadel (1982) developed a rapid method in which artificially inflicted wounds are lifted off the tissue after healing and stained with phloroglucinol. The colour intensity was used to indicate the level of lignification. For potato, Lulai and Orr (1995) measured the wound healing efficiency by determining the transpiration rate through the wound surface using a porometer. These methods generally require too sophisticated equipment, or are too time consuming to be used to screen germplasm. More importantly, from our observations, we considered that the continuity of lignification is more important in the healing of wounds than the thickness of the lignified layer, and that there appears to be little relationship between thickness of the lignified layer and continuity. Thus Yan Shu 1 tends to have good continuity, but thin lignified layers. We therefore developed a rapid method to assess continuity of the lignified layer to enable us to determine the wound-healing efficiency of cultivars at lower humidities. After staining of lignin by phloroglucinol, the continuity of the lignified layer can be easily assessed and scored by the naked eye in tissue sections cut by hand from wounds left to heal for 5 days. The average score for each wound $(0-1)$ was termed the Lignification index (L.I.) (see Materials and Methods for further details). This method is quick, as the staining is rapid (3 minutes), requires minimal equipment and can thus be used in developing countries of the tropics where sweetpotato is important as a staple crop but where laboratory facilities with microscopes are not available. 
Table 4 shows the L.I. for the five cultivars, measured in 7 trials. Consistently high L.I.s were observed for the cultivars Zapallo and Yan Shu 1, while SPK004 was consistently poor. The cultivars Kemb 10 and KSP 20 were more variable, and appeared to show some dependence on RH.

The relationship between L.I. and humidity is examined in more detail in Figure 3 which shows the L.I. for thirteen cultivars measured at three relative humidities (58, 65 and 97\%). At high humidity the L.I. is close to 1 for all cultivars. At lower humidities there is a wide range among cultivars in the ability to lignify; significant differences were found between all relative humidities $(\mathrm{P}<0.001)$, among the cultivars $(\mathrm{P}<0.001)$ and for the interaction between cultivar and relative humidity $(\mathrm{P}<0.001)$.

\section{Validity of L.I. as indicator of healing and storability}

Wound healing is considered important both to reduce water loss through a wound, and also to prevent entry of pathogens. We tested the validity of the L.I. as a measure of wound healing in terms of both these aspects.

\section{The relationship between the L.I. and water loss through the wound}

Water loss through wounds was measured directly in terms of transpiration rate using a modified leaf porometer. Figure 4 shows the transpiration rate over time through wounds healed at $76 \% \mathrm{RH}$ for the five key cultivars. The transpiration rate decreases during the wound healing process. This is partly due to desiccation of the top cell layers under the wound, and partly through lignification and wound periderm 
formation. Although cultivars showed a similar pattern, significant differences were observed among them at all time points. Consistent with the L.I., the transpiration rates through wounds in Zapallo and Yan Shu 1 were always lower than for Kemb 10, KSP 20 and SPK 004.

In Figure 4 the transpiration rates are also shown for two potato cultivars. It is worth noting that the water loss profiles of potato were different from those of sweetpotato. The transpiration rate through potato wounds decreased more rapidly after wounding, confirming the findings of Lulai et al. (1996). Thus the barrier under a potato wound forms more rapidly, or has a more effective sealing capacity than in sweetpotato. The barrier formed in potato does not stain with phloroglucinol/HCl, but stains with Sudan III, and is therefore assumed to consist mainly of suberin (Lulai and Morgan 1992). Suberin type waxes are known to prevent desiccation (Schönherr, 1976; Soliday et al., 1979, Vogt et al., 1983, Dean 1989). The barrier in sweetpotato on the other hand stains bright red with phloroglucinol/ $\mathrm{HCl}$ and is believed to be a ligno-suberin-like substance with more lignin character (McClure 1960).

The association between the presence/continuity of lignin and transpiration rate was assessed using the data of individual sweetpotato roots irrespective of the cultivar (Table 5). The distribution of the levels of transpiration rate were divided into 3 categories (as low, intermediate and high) and lignification was divided into 2 categories, according to the completeness of lignification. Pearson $\chi$ square tests indicated that lignification was significantly associated with lower transpiration rates at $6,8,10$ and 13 days after wounding. No association with the transpiration rate was 
only indicated on day 3 when presumably the wound healing process was not completed.

\section{The relationship between L.I. and pathogen invasion of the wound.}

The effectiveness of wound healing in protecting the wound against pathogen invasion was tested by placing mycelia of Rhizopus oryzae directly onto wounds at various stages during the healing process. Figure 5 shows the dimensions of lesions allowed to develop over 2 days for 12 cultivars. SPK004 is notable in the development of lesions on wounds even after 6 days of healing. A contingency table relating the incidence of rots to either the presence of lignin, or to the completeness of the lignified layer (Table 6), indicates that the latter is much more important in preventing rotting.. It appears that pathogens are unable to effectively degrade mature suberin (Kolattukudy, 1981; 1984), and the same is likely to be true for ligno-suberin complexes.

\section{Lignification index and storability (weight loss)}

The results above establish that continuity of the lignin layer and therefore the L.I. provides a valid indication of functional wound-healing for sweetpotatoes at suboptimal humidities. We have previously postulated that water loss is the main cause of deterioration for roots during marketing in the tropics (Rees et al., 2002). This suggests that the L.I. for a cultivar could provide an important indication of the potential shelf-life of that cultivar during marketing. Consistent with this, we find that high weight losses occur during storage for cultivars with poor lignification efficiency (Figure 6, correlation coefficient $-0.472, p=0.027$ ). This is in contrast with the 
findings of Walter et al., (1989) that the rate of lignification did not relate to the storability.

\section{L.I. and root dry matter content}

We found a relationship between root dry matter (DM) content and L.I. at lower humidities. The average root DM content for each cultivar is indicated on Figure 3 and is significantly negatively correlated with the cultivar L.I. measured at 58\% RH (p $=0.027)$ and nearly significant at $65 \% \mathrm{RH}(\mathrm{p}=0.073)$ but not at $97 \%$. Figures $7 \mathrm{a}-\mathrm{d}$

present the linear regression analysis for dry matter content and lignin index for four additional trials. In all cases there was a negative correlation between dry matter and lignin index ( $\mathrm{p}$ values $0.005,0.008,0.065,0.052)$. According to the regression models the probability that wounds heal decreases with increasing dry matter content, and, on average, if the dry matter content increases by $1 \%$, the L.I. decreases by approximately 0.05 .

It was also observed that the regression model in trial 5 was less steep than in trial 4, 6 and 7. This coincided with a higher relative humidity in trial 5, which was $75.9 \%$ as opposed to $71.1,67.3$ and $64.7 \%$ in the other trials. Although the difference in relative humidity did not affect the cultivars with a low dry matter content, it did affect the cultivars with a higher dry matter content. Possibly there is an interaction between the dry matter content of the cultivar and relative humidity necessary for wound healing.

The mechanism by which the DM content might affect wound healing is not understood, and requires further investigation. It is possible that wound healing ability 
is directly related to the rate of desiccation of the tissue. Porometer readings indicate that tissue with a high DM content initially lose water at the same rate as tissue with a low DM content, and might therefore reach a critical level of moisture content more rapidly than tissue with a low DM content. The hypothesis would be that below a critical level of moisture content the tissue stress results in failure to form the protective lignified layer under the wound.

There would appear to be several factors affecting the wound healing ability since there were some consistent outlying cultivars. The cultivar KSP 20 consistently healed less well than predicted from the DM/lignin index relationship, while Caplina and Yarada consistently healed better than expected.

The relationship seen here between L.I. and DM may explain previous results that we have obtained in which we observed that high dry matter cultivars in Tanzania tend to have a shorter shelf-life (Rees et al., 2002).

\section{Conclusions}

Under sub-optimal humidities $(65 \% \pm 10)$ the wound healing process in sweetpotato follows a similar pattern to wound healing under curing conditions (high humidity). However, the thickness of the desiccated cell layer, and hence the depth of the lignified layer is affected by both cultivar and humidity. Some cultivars consistently failed to produce a lignified layer and for others the layer is often not continuous. The continuity of the lignified layer is more important for effectiveness of wound healing than the actual thickness. 
Wound healing efficiency as measured by the lignification index was found to be a major factor for the shelf-life of sweetpotato cultivars. Lignification of wounds correlates with reduced rate of weight loss and fungal infection. A high dry matter content in cultivars correlated with a low lignification index. This relationship was consistent for 5 trials, including 34 cultivars.

\section{Materials and Methods}

Eight storage trials were conducted. Table 1a presents relevant field and experimental information for each of the trials, while Table $1 \mathrm{~b}$ presents the cultivars included. The storage conditions used were as follows:

\section{Method A (trial 1 and 2, based at NRI, UK)}

Twelve plastic dustbins (B\&Q) were placed in a temperature controlled room at $26^{\circ} \mathrm{C}$. Within each of these, approximately 20 sweetpotato roots (weighing about $5 \mathrm{~kg}$ in total) were placed on a platform. The platform was constructed from a plastic plant support and plastic covered chicken wire, and was supported at a height of about 30 $\mathrm{cm}$. In order to maintain high humidity a layer of water (approximately $70 \mathrm{~mm}$ ) was placed in the bottom of each bin, and air was bubbled through this at a rate of approximately $31 \cdot \mathrm{min}^{-1} \cdot \mathrm{bin}^{-1}$. A single pump (Charles Austin Pumps Ltd, UK) was used to provide an air-flow which was divided using a manifold to supply all 12 bins. The humidity was measured at hourly intervals in six of the twelve bins using humidity probes (Vaisala, Helsinki, Finland), and recorded by data-loggers (Grant Instruments Ltd., Barrington, Cambridge) and was found to remain between 76 and $100 \%$. 
Method B (trial 3 based at NRI)

.One randomly selected root per cultivar/ trial was placed in each of eight cardboard boxes $\left(22\right.$ roots/box), which were kept for 10 weeks in a $\mathrm{CT}$ room maintained at $25^{\circ} \mathrm{C}$ and 60\%RH. T and RH recorded using Tiny Talk data loggers (Gemini, Chichester, UK) were $25 \pm 0.5^{\circ} \mathrm{C}$ and $55 \% \pm 6 \%$.

Method C (Trials 4, 5, 6 and 7 based at NARL, Nairobi, Kenya).

Roots were stored in crates. Each crate contained up to 30 roots with an equal number of roots for each cultivar. During the first two days the boxes were lined with plastic sheets or dustbin liners in order to simulate the high humidity in closed sacks to which the roots would be exposed when transported to the market. In six boxes the RH was measured every 30 minutes, using RH probes and recorded using data loggers as described above. The Temperature fluctuated between 18 and $27^{\circ} \mathrm{C}$ and $\mathrm{RH}$ fluctuated between 45 and $95 \%$.

\section{Method D (Trial 8 based at NRI, UK)}

The roots were maintained at 3 different levels of humidity, in three chambers located within a controlled temperature $(\mathrm{CT})$ room maintained at $25^{\circ} \mathrm{C}$. In one chamber a high RH was maintained by means of an air flow of $3.51 \cdot \mathrm{hr}^{-1}$ through a layer of water in the base of the chamber. Humidification of the air was improved by using fish-tank stones for air dispersal. The RH achieved was 97\%.

For the two other chambers an intermediate humidity was maintained using two supplies of air, one of low humidity (sourced from outside the CT-room) and one of high humidity (obtained by bubbling through water). The supply of these two sources 
of air was controlled using an adjustable humidity sensor placed within the chamber. The humidities attained were in the range of $56.6-62.3$ and $64.5-70.5 \%$ with an average of $58 \%$ and $65 \%$ respectively.

\section{Wounding}

Artificial wounds were inflicted by peeling a portion of the surface with a potato peeler. The area of tissue removed was approximately 2 x $5 \mathrm{~cm}$ and $1.7 \mathrm{~mm}$ deep.

\section{Staining and microscopy}

Both fresh and embedded tissue sections were studied. Fresh sections were hand cut with a razor blade (Wilkinson Sword) at a thickness of $2-7$ cells. The sections were stained with phloroglucinol ( $1 \%$ in $95 \%$ ethanol) for $2 \mathrm{~min}$, transferred to concentrated $\mathrm{HCl}$ for $30 \mathrm{~s}$, then rinsed in water for $30 \mathrm{~s}$. Four sections per wound were assessed.

For the preparation of embedded sections tissue blocks of $7 \times 7 \times 7 \mathrm{~mm}$, including both wound surface and native periderm, were cut and fixed in a Formalin Acetic Acid solution (Ethanol 70\%, Formalin 5\%, Acetic Acid 5\%). The tissue blocks were than dehyrdated in toluene (99\%) and embedded in paraffin wax (Paraplast Plus, Sigma). Sections of $15 \mu \mathrm{m}$ thickness were cut using a microtome. Before staining, the embedded sections were dehydrated in a series of toluene $(2 \mathrm{x} 100 \%)$ and ethanol $(2 \mathrm{x}$ $100 \%, 1 \times 90 \%$ (last)). Sections were stained for lignin with Phloroglucinol and $\mathrm{HCl}$ as described above. The morphology of the lignified layer was assessed at 100x magnification using a microscope (Leitz, UK) equipped with a graticule. Micrographs were taken using a Minolta X-700 camera mounted on the microscope. 


\section{Lignification Index}

Four thin cross sections with a depth of $10 \mathrm{~mm}$ and approx $0.5 \mathrm{~mm}$ thick were cut from the wounds using a razorblade. The sections were stained with phloroglucinol as described above. Each wound was given a score between 0 and 1 based on the continuity of lignification across the wound (See Table 2 for examples). The average lignification score for the 4 sections of each wound was called the 'lignification index', L.I..

\section{Rate of water loss}

Transpiration rate through the wounded surface of sweetpotato roots was determined using a porometer (PP Systems Ltd, Hitchin, UK). The leaf-chamber was adapted for this purpose by replacing the rectangular aperture with a round aperture of $1.5 \mathrm{~cm}$ diameter, the lower clamp was removed and the head was padded with soft black foam to provide a seal and to avoid damage to the surface during the measurements. The mass flow rate of the air through the chamber was set at $54.5 \mathrm{~cm}^{3} \cdot \mathrm{min}^{-1}$. As the vapour conductance through sweetpotato wounded surface is a passive diffusion process, the use of desiccant was not considered necessary.

\section{Dry matter contents}

The dry matter contents were assessed using approximately $20 \mathrm{~g}$ of diced or sliced tissue, dried in an oven at $80^{\circ} \mathrm{C}$ for 48 hours. 


\section{Microbial invasion}

Roots with wounds were kept under sub-optimal conditions for 3, 6 and 10 days after which they were assessed for susceptibility to Rhizopus oryzae. $9 \mathrm{~mm}$ mycelial discs were cut from the border of a 2-day-old PDA (potato dextrin agar) culture of $R$. oryzae and placed on the wound with the mycelial side facing down. roots were incubated for 2 days in transparent polyethylene bags $(40 \mathrm{~cm}$ x $50 \mathrm{~cm})$ which were each punctured with 16 holes for ventilation. The relative humidity and the temperature in the bags were recorded with using electronic data loggers (Onset Computer Corp. 1998) and were found to be 94.2 to $97.5 \%$ and $21.7-24.0^{\circ} \mathrm{C}$ respectively.

In order to assess the extent of tissue degradation by the inoculated pathogens, the roots/tubers were then cut longitudinally through the point of inoculation (Duarte and Clark, 1993) and measurements of the lesions were taken. The wounds were further assessed for lignification as described above.

\section{Statistical analysis}

All analyses were carried out using Genstat (Rothamsted, UK). Analysis of variance was used to assess differences among the cultivars in thickness of lignified layers and number of lignified cell layers. The association between lignification and weight loss, transpiration rate and susceptibility to $R$. oryzae was determined using contingency tables for which significance was tested using the Pearson Chi Square tests.

Categories were created for the level of weight loss and transpiration based on their distribution. For susceptibility to rotting the two categories constituted no rotting and rotting. The relationships between rate of water loss and storage time, and between the 
lignin index and DM content were assessed using linear regression. For this, the mean values of each cultivar were taken.

\section{Acknowledgements}

The authors would like to thank all collaborators at International Potato Center (CIP),

National Agricultural Research Laboratories at KARI, Nairobi, Kenya, the Tanzanian

National Root and Tuber Crops Programme, Ukiriguru, Tanzania and USDA-ARS,

USA. Further Alan Hilton and Joshua Ngigi are acknowledged. 


\section{Literature cited}

Akhimienho HD (1999) The control of vascular streaking (primary physiological disorder) in fresh cassava root. Mphil Thesis, Cranfield University, Silsoe College, Silsoe

Artschwager E, Starrett RC (1931) Suberization and wound-periderm formation in sweetpotatoe and gladiolus as affected by temperature and relative humidity. Journal of Agricultural research, 43; 3, 353-364

Collins WW, Walter WM (1985) Fresh roots for human consumption. In JC Bouwkamp, ed, Sweet Potato Products: A Natural Resource for the Tropics. CRC Press Inc, Boca Raton, pp 153-173

Dean BB (1989) Deposition of Aliphatic Suberin monomers and associated alkanes during aging of Solanum tuberosum L. tuber tissue at different temperatures. Plant Physiology, 89: 1021-1023.

Duarte V, Clark CA (1993) Interaction of Erwinia chrysanthemi and Fusarium solani on sweet potato. Plant Disease 77: 733 - 735

Jenkins PD, (1982) Losses in sweet potatoes (Ipomoea batatas) stored under traditional conditions in Bangladesh. Tropical Science, 24 (1), 17-28

Kolattukudy P.E., 1981. Structure biosynthesis, and biodegradation of cutin and suberin. Annual Reviews of Plant Physiology; 32, 539-567. 
Kolattukudy PE, (1984) Biochemistry and function of cutin and suberin. Canadian Journal of Botany, 62: 1886-1892

Kushman LJ, Wright FS (1969) Sweet potato storage. USDA Agriculture Handbook no. 358

Lulai EC, Orr PH (1995) Porometer measurements indicate wound severity and tuber maturity affect the early stages of wound-healing. American Potato Journal 72: 225241

Lulai EC, Morgan WC (1992) Histochemical probing of potato periderm with neutral red: a sensitive cytofluorochrome for hydrophobic domain of suberin. Biotechnic and Histochemistry 67: 185-195

Lulai EC, Glynn MT, Orr PH (1996) Cellular changes and physiological responses to tuber pressure bruising. American Potato Journal 73: 197-209

McClure TT (1960) Chlorogenic acid accumulation and wound healing in sweet potato roots. American Journal of Botany 47: 277-280

Morris LL, Mann LK (1955) Wound healing, keeping quality, and compositional changes during curing and storage of sweet potatoes. Hilgardia, 24;7, 143-183 
Nielsen LW Johnson JT (1974) Postharvest temperature effects on wound healing and surface rot in sweetpotato. Phytopathology 64: 967-970.

Passam HC, Read SJ, Rickard JE (1976) Wound repair in yam tubers: physiological processes during repair. New Phytologist, 77; 325-331

Picha DH (1986) Weight loss in sweet potatoes during curing and storage: contribution of transpiration and respiration. Journal of the American Society for Horticultural Science 11: 889-892

Rees D, Kapinga R, Rwiza E, Mohammed R, Van Oirschot Q, Carey E, Westby A (1998) The potential for extending shelf-life of sweet potato in East Africa through cultivar selection. Tropical Agriculture (Trinidad) 75; 208-211

Rees D, Kapinga R, Mtunda K, Chilosa D, Rwiza E, Kilima M, Kiozya H, Munisi R (2001) Damage reduces both market value and shelf-life of sweetpotato: a case study of urban markets in Tanzania. Trop. Sci., 41, 142-150

Rees D, Van Oirschot QEA, Amour R, Rwiza E, Kapinga R, Carey T (2002) Cultivar variation in keeping quality of sweetpotatoes. Postharv. Biol.Tech (In press).

Rickard JE (1985) Physiological deterioration in cassava roots. J. Sci. Food Agri., 36, $167-176$ 
Schönherr J (1976) Water permeability of isolated cuticular membranes: the effect of cuticular waxes on diffusion of water. Planta, 131: 159-164.

Soliday CL, Kolattukudy PE, Davis RW (1979) Chemical and ultrastructural evidence that waxes associated with the suberin polymer constitute the major diffusion barrier to water vapor in potato tuber (Solanum tuberosum L.). Planta, 146: 607-614

St Amand PC, Randle WM (1991) Ethylene production as a possible indicator of wound healing in roots of several sweet potato cultivars. Euphytica 53: 97-102

Strider DL, McCombs CL (1958) Rate of wound phellem formation in the sweet potato. American Society for Horticultural Science 72: 435-442

Vogt E, Schönherr J, Schmidt HW (1983) Water permeability of periderm membranes isolated enzymatically from potato tubers (Solanum tuberosum L.). Planta; 158:4; 294-301.

Walter WM, Schadel WE (1983) Structure and composition of normal skin (periderm) and wound tissue from cured sweet potatoes. Journal of the American Society for Horticultural Science, 108, 909-914

Walter WM, Schadel WE (1982) A rapid method for evaluating curing progress in sweet potatoes. Journal of the American Society for Horticultural Science 107: 11291133 
Walter WM, Hammett LK, Giesbrecht FG (1989). Wound healing in sweet potato and stability during subsequent storage. Journal of the American Society for Horticultural Science, $114,94-100$.

Weimer JL, Harter LL (1921) Wound cork formation in the sweet potato. Journal of Agricultural Research, 21;9, 637-647

Woolfe JA (1992) Sweet Potato. An Untapped Food Resource. Cambridge University Press, Cambridge 


\section{Figure captions and legends}

Figure 1 A, B, C, D, E, F.

Variability in depth of desiccation depending on cultivar and relative humidity.

Transverse sections through wounded roots at 3 days after wounding. From left to

right: 97\% RH, 65\% RH, 58\% RH. A Zapallo (Pumpkin), B. BP1SP2;, C. Caplina;

D. Yanshu, E. SPK004, F. Kemb 10

Figure $2 \mathrm{~A}, \mathrm{~B}$ C, D

Sections through sweetpotato wounds at 6 days after wounding when the roots were

kept at $71.1 \% \mathrm{RH}$ and $\mathrm{T}=20.9 \pm 1.6$. Sections were stained with phloroglucinol $(1 \%$ in ethanol 95\%) as described in Material and Methods. Magnification: x 40 or x 100. Bar $=100 \mu \mathrm{m}$
A. Zapallo: thin desiccated cell layer (x 100)
B. KSP 20: 20 to 25 desiccated cell layers above patchy lignification (x40)
C. Kemb 10: onset of lignification (x40)
D. SPK 004: no lignified cell layers (x 40)

Figure 3.

The lignification index of 13 sweetpotato cultivars measured after healing at three relative humidities $(58 \%, 65 \%$ and 97\%). Roots were obtained from Trial 8. Experiment was set up in 3 replicates using at least 4 roots per rep, and analysis conducted at 3 and 6 days. As there was no significant effect of days the means of 
both data sets are displayed here. Cultivar root dry matter contents measured using 3 roots per cultivar are given at the top of the graph.

Figure 4

Transpiration rate through artificially inflicted wounds for 5 sweetpotato and 2 potato cultivars. Roots were obtained from trial 5. Each value is the mean of 5-10 measurements taken with a porometer at the wound site. Healing conditions $20^{\circ} \mathrm{C}$, $76 \%$ RH.

Figure 5

The dimensions of lesions of $R$. oryzae placed on 3, 6 or 10 day old wounds. Roots were obtained from trials 4 and 5 Healing conditions $21^{\circ} \mathrm{C}$ and $71 \%$ and $76 \% \mathrm{RH}$ respectively. Freshly cut wounds were used as controls. Mycelial plugs were placed on the wound and the roots were incubated for 2 days in plastic bags to maintain humidity $\left(\mathrm{RH}=95 \% ; \mathrm{T}=21-25^{\circ} \mathrm{C}\right)\left(\mathrm{LSD}_{3 \text { days }}=6.96 ; \mathrm{LSD}_{6 \text { days }}=5.74 ; \mathrm{LSD}_{10 \text { days }}=\right.$ 7.02).

Figure 6

The relationship between cultivar L.I. and \% root weight loss after 10 weeks of storage. Each point corresponds to a cultivar. 
Roots were obtained from trial 3. L.I. was measured after curing at $65 \% \mathrm{RH}$ and $25^{\circ} \mathrm{C}$. Storage conditions were $19+/-1^{\circ} \mathrm{C} \mathrm{RH} 60-70 \%$ the roots were kept in $10 \mathrm{reps}$, in cardboard boxes, each rep contained one root per cultivar).

\section{Figure 7}

The relationship between cultivar DM content and the lignin index. Each point presents 1 cultivar.

\section{Tables}




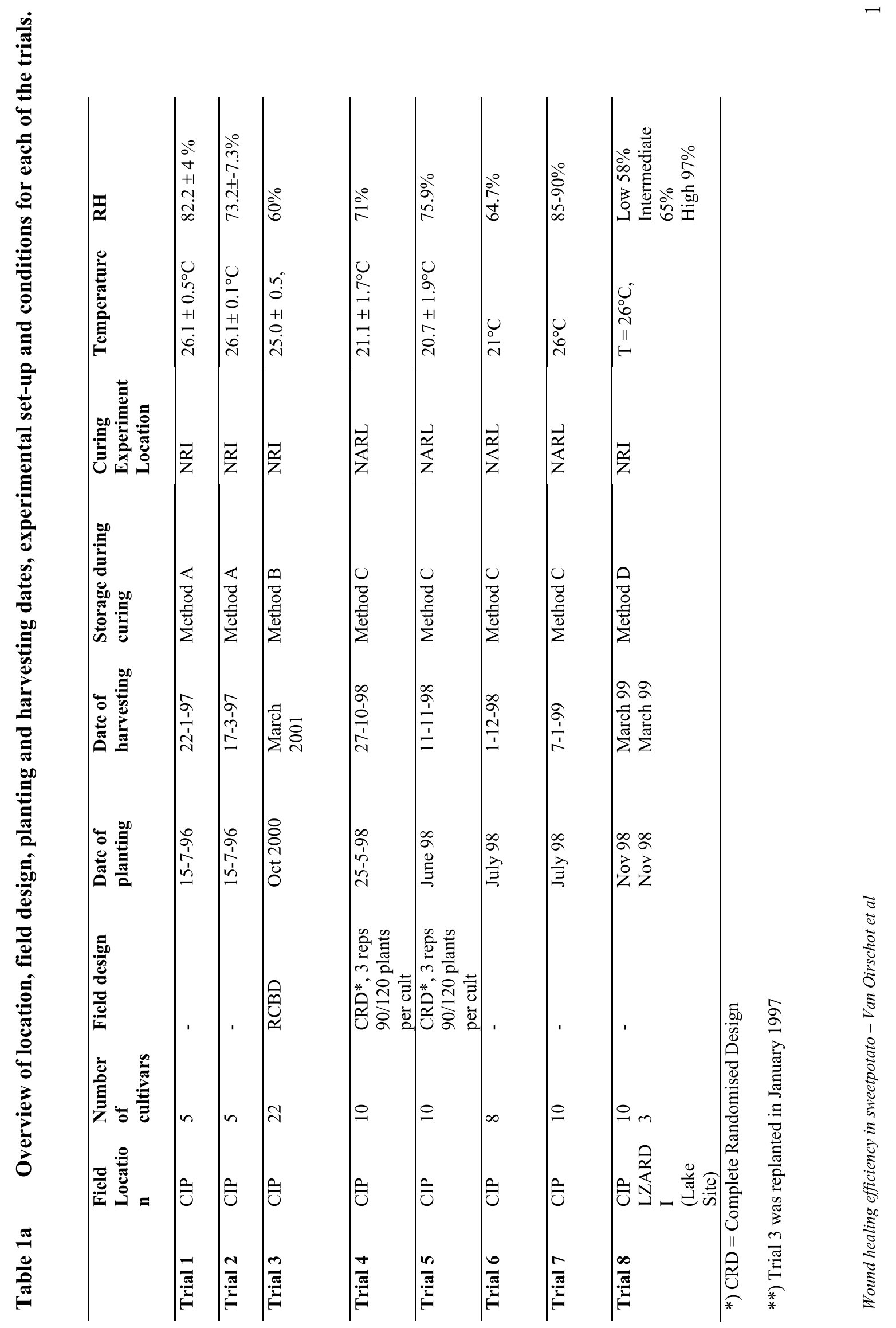



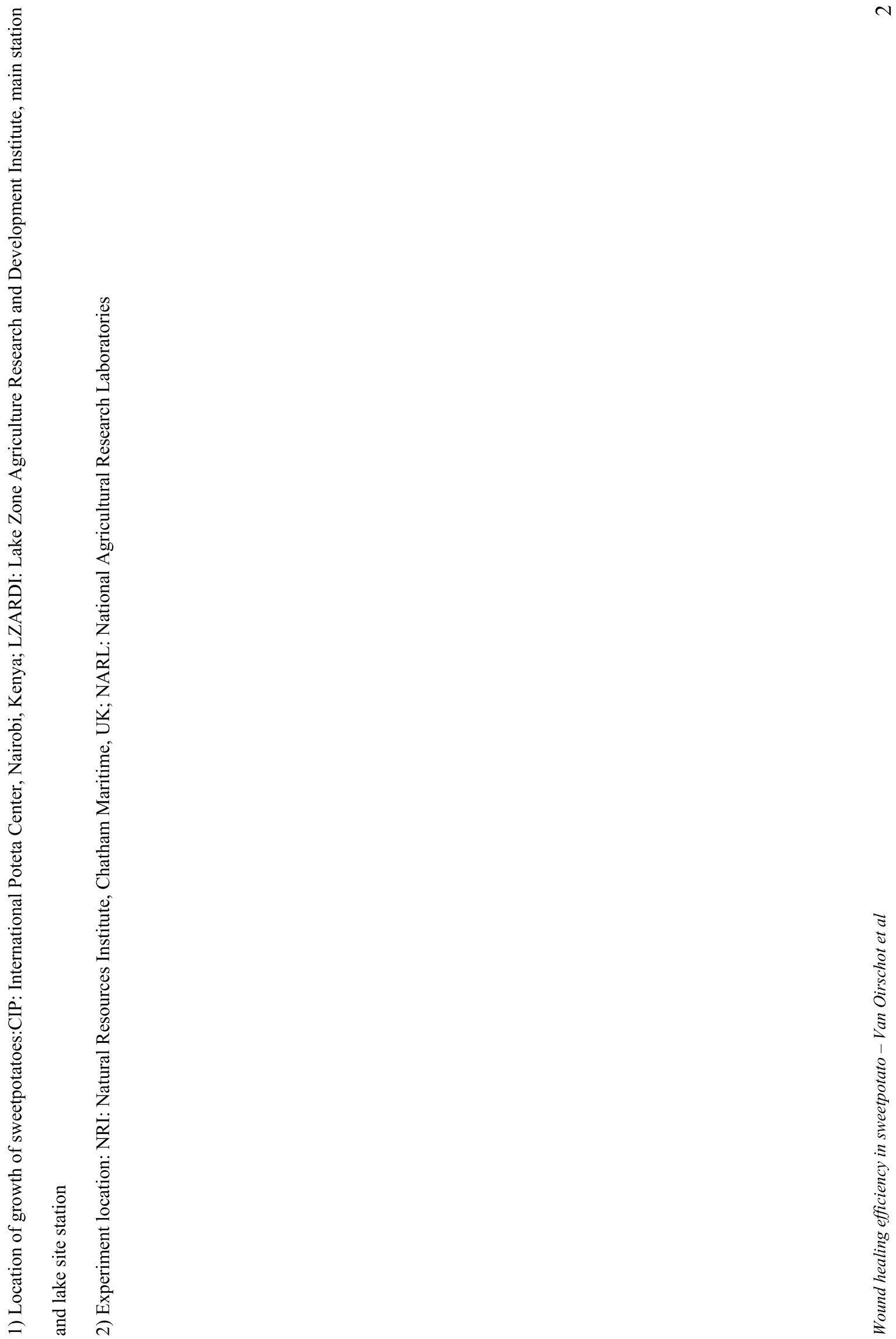
Table 1b Overview of the cultivars used in each of the trials

\begin{tabular}{|c|c|c|c|c|c|}
\hline Trial & Cultivars & & & & \\
\hline Trial 1 & Kemb 10 & KSP 20 & SPK 004 & Yan Shu 1 & Zapallo \\
\hline Trial 2 & Kemb 10 & KSP 20 & SPK 004 & Yan Shu 1 & Zapallo \\
\hline Trial 3 & $\begin{array}{l}\text { Jewel } \\
\text { Budagala* } \\
\text { Yanshu } \\
\text { Beauregard }\end{array}$ & $\begin{array}{l}\text { Sinia } \\
\text { KSP20* } \\
\text { Sinia B } \\
\text { Kemb10* }\end{array}$ & $\begin{array}{l}\text { Zapallo* } \\
\text { SPN/0 } \\
\text { Hernandez } \\
\text { Polista }\end{array}$ & $\begin{array}{l}\text { Kagole } \\
\text { Iboja } \\
\text { Bilagala } \\
\text { Mwananmonde } \\
\text { SPK004 } \\
\end{array}$ & L-86-33 \\
\hline Trial 4 & $\begin{array}{l}\text { BP1-SP-2 } \\
\text { Caplina }\end{array}$ & $\begin{array}{l}\text { Julian } \\
\text { Kemb } 10\end{array}$ & $\begin{array}{l}\text { KSP } 20 \\
\text { Salyboro }\end{array}$ & $\begin{array}{l}\text { SPK } 004 \\
\text { Yarada }\end{array}$ & $\begin{array}{l}\text { Yan Shu } 1 \\
\text { Zapallo }\end{array}$ \\
\hline Trial 5 & $\begin{array}{l}\text { BP1-SP-2 } \\
\text { Caplina }\end{array}$ & $\begin{array}{l}\text { Julian } \\
\text { Kemb } 10\end{array}$ & $\begin{array}{l}\text { KSP } 20 \\
\text { Salyboro }\end{array}$ & $\begin{array}{l}\text { SPK } 004 \\
\text { Yarada }\end{array}$ & $\begin{array}{l}\text { Yan Shu } 1 \\
\text { Zapallo }\end{array}$ \\
\hline Trial 6 & $\begin{array}{l}\text { BP1-SP-2 } \\
\text { Caplina }\end{array}$ & $\begin{array}{l}\text { Julian } \\
\text { Kemb } 10\end{array}$ & $\begin{array}{l}\text { KSP } 20 \\
\text { Salyboro }\end{array}$ & $\begin{array}{l}\text { SPK } 004 \\
\text { Yarada }\end{array}$ & $\begin{array}{l}\text { Yan Shu } 1 \\
\text { Zapallo }\end{array}$ \\
\hline Trial 7 & $\begin{array}{l}\text { BP1-SP-2 } \\
\text { Caplina }\end{array}$ & $\begin{array}{l}\text { Julian } \\
\text { Kemb } 10\end{array}$ & $\begin{array}{l}\text { KSP } 20 \\
\text { Salyboro }\end{array}$ & SPK 004 & $\begin{array}{l}\text { Yan Shu } 1 \\
\text { Zapallo }\end{array}$ \\
\hline Trial 8 & $\begin{array}{l}\text { BP1-SP-2 } \\
\text { Caplina }\end{array}$ & $\begin{array}{l}\text { Julian } \\
\text { Kemb } 10\end{array}$ & $\begin{array}{l}\text { KSP } 20 \\
\text { Salyboro } \\
\text { SPK } 004\end{array}$ & $\begin{array}{l}\text { Yarada } \\
\text { Yan Shu } 1 \\
\text { Zapallo }\end{array}$ & $\begin{array}{l}\text { Polista } \\
\text { SPN/0 } \\
\text { SP/93/2 }\end{array}$ \\
\hline
\end{tabular}

* Roots of these cultivars grown in two separate field trials were considered separately. 
Table 2. Scores for lignification of sweetpotato wound sections representing continuity of lignified layer

\begin{tabular}{lcccc}
\hline & Score & Completeness of the lignin layer \\
\hline $\begin{array}{l}\text { Lignifi } \\
\text { cation } \\
\text { score }\end{array}$ & $\begin{array}{c}\text { Presence } \\
\text { of lignin }\end{array}$ & $\begin{array}{c}\text { Completeness of } \\
\text { lignification }\end{array}$ & $\begin{array}{c}\text { Distribution of } \\
\text { lignin in wound }\end{array}$ \\
\hline $\begin{array}{l}\text { Complete lignification } \\
\text { Patchy lignification }\end{array}$ & 1 & 1 & 1 & 0 \\
No lignification at all & 0.5 & 1 & 0
\end{tabular}


Table 3a The number of lignified cell layers following artificial wounding and healing of roots of 5 cultivars of sweetpotato.

Roots were obtained from Trial 1 after 1 and 4 weeks of storage. Measurements were taken for 5 wounds per cultivar for each storage time. Healing conditions: $26^{\circ} \mathrm{C}$ and $82 \%$ RH. No significant effects of storage time were found.

\begin{tabular}{lcccc}
\hline Days after wounding & $\mathbf{2}$ & $\mathbf{3}$ & $\mathbf{4}$ & $\mathbf{5}$ \\
\hline Yan Shu 1 & 1.41 & 1.29 & 2.04 & 2.28 \\
Kemb 10 & 0.96 & 2.19 & 2.39 & 3.36 \\
KSP 20 & 0.56 & 1.56 & 3.65 & 3.09 \\
Zapallo & 1.21 & 1.96 & 2.15 & 2.88 \\
SPK 004 & 0.47 & 0.97 & 0.47 & 1.75 \\
\hline Cultivar effect (P & $\mathrm{ns}$ & $\mathrm{ns}$ & $<0.001$ & 0.076 \\
value) & & & & \\
LSD & 0.85 & 1.00 & 1.24 & 1.73 \\
\hline
\end{tabular}


Table 3b The thickness of the desiccated and lignified cell layers $(\mu \mathrm{m})$ during healing after artificial wounding of roots of 5 cultivars of sweetpotato.

Measurements were taken using a microscope equipped with a graticule for 4 sections per root, after 1 and 6 weeks of storage. 5 and 4 roots obtained from trial 2 were assessed per cultivar after 1 and 6 weeks respectively. In some cases it was not possible to determine the thickness of the desiccated cell layers, and this was treated as missing data. Healing conditions: $26^{\circ} \mathrm{C}$ and $73 \% \mathrm{RH}$.

\begin{tabular}{|c|c|c|c|c|c|c|c|c|c|}
\hline \multirow{2}{*}{$\begin{array}{l}\text { Days of } \\
\text { healing }\end{array}$} & & \multicolumn{2}{|l|}{2 days } & \multicolumn{2}{|l|}{4 days } & \multicolumn{2}{|l|}{6 days } & \multicolumn{2}{|l|}{10 days } \\
\hline & $\begin{array}{c}\text { Storage } \\
\text { time from } \\
\text { harvest }\end{array}$ & $\begin{array}{c}\text { Desiccated } \\
\text { cells }\end{array}$ & $\begin{array}{l}\text { Lignified } \\
\text { cells }\end{array}$ & $\begin{array}{c}\text { Desiccated } \\
\text { cells }\end{array}$ & $\begin{array}{l}\begin{array}{l}\text { Lignified } \\
\text { cells }\end{array} \\
\text { cils }\end{array}$ & $\begin{array}{c}\text { Desiccated } \\
\text { cells }\end{array}$ & $\begin{array}{l}\text { Lignified } \\
\text { cells }\end{array}$ & $\begin{array}{c}\text { Desiccated } \\
\text { cells }\end{array}$ & $\begin{array}{l}\text { Lignified } \\
\text { cells }\end{array}$ \\
\hline \multirow[t]{2}{*}{ Yan Shu 1} & 1 week & \multirow{2}{*}{23.2} & \multirow{2}{*}{22.8} & \multirow{2}{*}{24.4} & \multirow{2}{*}{22.7} & \multirow{2}{*}{18.2} & \multirow{2}{*}{25.3} & 22.6 & 27.4 \\
\hline & 6 weeks & & & & & & & 20.5 & 29.2 \\
\hline \multirow[t]{2}{*}{ Kemb 10} & 1 week & \multirow{2}{*}{19.4} & \multirow{2}{*}{5.8} & \multirow{2}{*}{26.5} & \multirow{2}{*}{20} & \multirow{2}{*}{14.2} & \multirow{2}{*}{6.4} & 21 & 22 \\
\hline & 6 weeks & & & & & & & 75 & 2 \\
\hline \multirow[t]{2}{*}{ KSP 20} & 1 week & \multirow{2}{*}{19.4} & \multirow{2}{*}{13.7} & \multirow{2}{*}{38.6} & \multirow{2}{*}{28.4} & \multirow{2}{*}{22.7} & \multirow{2}{*}{38.4} & 44 & 34.2 \\
\hline & 6 weeks & & & & & & & 16 & 32.5 \\
\hline \multirow[t]{2}{*}{ Zapallo } & 1 week & \multirow{2}{*}{15.5} & \multirow{2}{*}{20.1} & \multirow{2}{*}{21.4} & \multirow{2}{*}{32.6} & \multirow{2}{*}{11.9} & \multirow{2}{*}{29.1} & 16.8 & 27.2 \\
\hline & 6 weeks & & & & & & & 16.2 & 19.8 \\
\hline \multirow[t]{2}{*}{ SPK 004} & 1 week & \multirow{2}{*}{19.8} & \multirow{2}{*}{3.9} & 46 & 53 & 248 & 124 & 58 & 19.6 \\
\hline & 6 weeks & & & & & & 12.7 & 122.8 & 3.5 \\
\hline $\begin{array}{l}\text { Stor. Effect } \\
\text { P value }\end{array}$ & & Ns & Ns & Ns & Ns & Ns & Ns & 0.013 & 0.019 \\
\hline $\begin{array}{l}\text { Cult. effect } \\
\text { P value }\end{array}$ & & Ns & $<0.001$ & & 0.011 & Ns & $<0.001$ & $<0.001$ & 0.001 \\
\hline Cult.Stor & & & & 0.004 & & & & $<0.001$ & \\
\hline LSD Cult & & 16.95 & 7.76 & & 16.36 & & 12.76 & & \\
\hline $\begin{array}{l}\text { LSD } \\
\text { Cult.Stor }\end{array}$ & & & & & & & & 32.04 & 16.84 \\
\hline
\end{tabular}

$L S D=$ Least Significant difference

Table 4 The lignin index of 5 sweetpotato cultivars as determined in 5

trials. For Trial 1 and 2, measurements were repeated after 4 and 6 weeks of storage respectively. At least 4 roots were assessed per cultivar in each trial. 


\begin{tabular}{|c|c|c|c|c|c|c|c|}
\hline & Trial 1 & $\begin{array}{l}\text { Trial } 1 \\
\text { (4 wks) }\end{array}$ & Trial 2 & $\begin{array}{r}\text { Trial } 2 \\
(6 \text { wks) }\end{array}$ & Trial 4 & Trial 5 & Trial 7 \\
\hline Temperature $^{\circ} \mathrm{C}$ & 26 & 26 & 26 & 26 & 21 & 20 & 23 \\
\hline RH (\%) & 82 & 82 & 73 & 73 & 71 & 76 & 65 \\
\hline$\overline{\text { Zapallo }}$ & 1 & 0.82 & 1 & 0.95 & 0.89 & 1 & 0.79 \\
\hline Yan Shu 1 & 0.8 & 0.9 & 1 & 1 & 0.96 & 0.98 & 0.95 \\
\hline KSP 20 & 0.85 & 0.91 & 0.8 & 0.9 & 0.3 & 0.58 & 0.33 \\
\hline Kemb 10 & 1 & 0.6 & 0.45 & 0.16 & 0.39 & 0.79 & 0.25 \\
\hline SPK 004 & 0.29 & 0.35 & 0.38 & 0.3 & 0.15 & 0.31 & 0.15 \\
\hline
\end{tabular}


Table 5 Association between lignification and the rate of water loss through wounds after 3, 6, 8, 10 and 13 days of healing. Data were collected from

Trial 4. Healing conditions: $21^{\circ} \mathrm{C} 71 \% \mathrm{RH}$

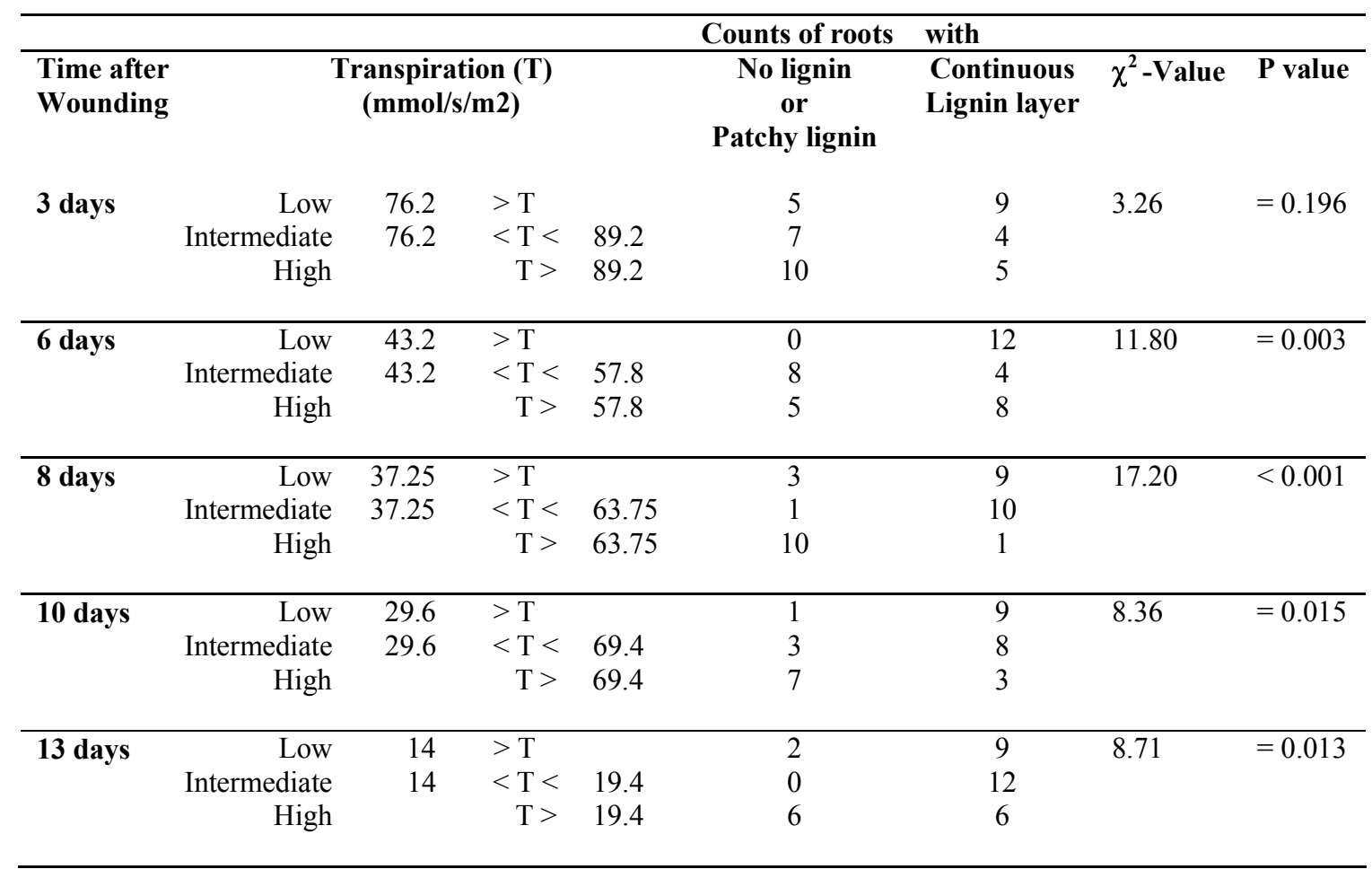


Table 6 Contingency table using the incidences of roots rotting and/ or

\section{lignification.}

In (A) patchy lignified roots were grouped with complete lignified roots, and in (B) patchy lignification was grouped with 'no lignin'.

\begin{tabular}{|c|c|c|c|c|c|}
\hline \multirow[b]{2}{*}{$\begin{array}{l}\text { Time } \\
\text { after } \\
\text { woundi } \\
\text { ng }\end{array}$} & \multirow[b]{2}{*}{ Rotting } & \multicolumn{2}{|c|}{ (A) Presence of lignin } & \multicolumn{2}{|c|}{ (B) Completeness of lignified layer } \\
\hline & & No Lignin & $\begin{array}{l}\text { Patchy lignin } \\
\text { Complete } \\
\text { lignification }\end{array}$ & $\begin{array}{l}\text { - No lignin } \\
\text { - Patchy lignin }\end{array}$ & $\begin{array}{l}\text { Complete } \\
\text { lignification }\end{array}$ \\
\hline \multirow[t]{2}{*}{ Day 3} & $\begin{array}{l}\text { No Rotting } \\
\text { Rotting }\end{array}$ & $\begin{array}{l}11 \\
18\end{array}$ & 26 & $\begin{array}{l}14 \\
28\end{array}$ & $\begin{array}{l}23 \\
21\end{array}$ \\
\hline & & $\begin{array}{l}\text { Pearsor } \\
\text { Fisher's }\end{array}$ & $\begin{array}{l}\text { hi Square }=0.46 \\
=0.496 \\
\text { ct test: } P=0.6455\end{array}$ & $\begin{array}{r}\text { Pearson C } \\
P \\
\text { Fisher's exa }\end{array}$ & $\begin{array}{l}\text { gquare }=6.71 \\
.010 \\
\text { est: } P=0.01544\end{array}$ \\
\hline Day6 & $\begin{array}{l}\text { No Rotting } \\
\text { Rotting }\end{array}$ & $\begin{array}{c}5 \\
15 \\
\text { Pearso } \\
\text { Fisher's }\end{array}$ & $\begin{array}{l}28 \\
19 \\
\\
\text { hi Square }=\mathbf{3 . 1 4} \\
=\mathbf{0 . 0 7 6} \\
\text { ct test: } \mathbf{P}=\mathbf{0 . 0 8 6 1}\end{array}$ & $\begin{array}{c}5 \\
26 \\
\\
\text { Pearson C } \\
\text { P } \\
\text { Fisher's ex }\end{array}$ & $\begin{array}{l}28 \\
8 \\
\\
\text { quare }=\mathbf{2 5 . 3 3} \\
.001 \\
\text { test: } \mathbf{P}<\mathbf{0 . 0 0 1}\end{array}$ \\
\hline
\end{tabular}


A: Zapallo (Pumpkin)

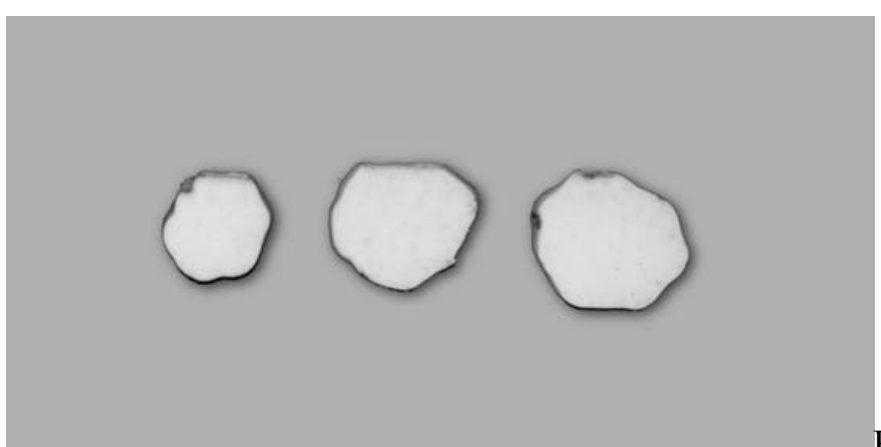

B: BP1-SP2
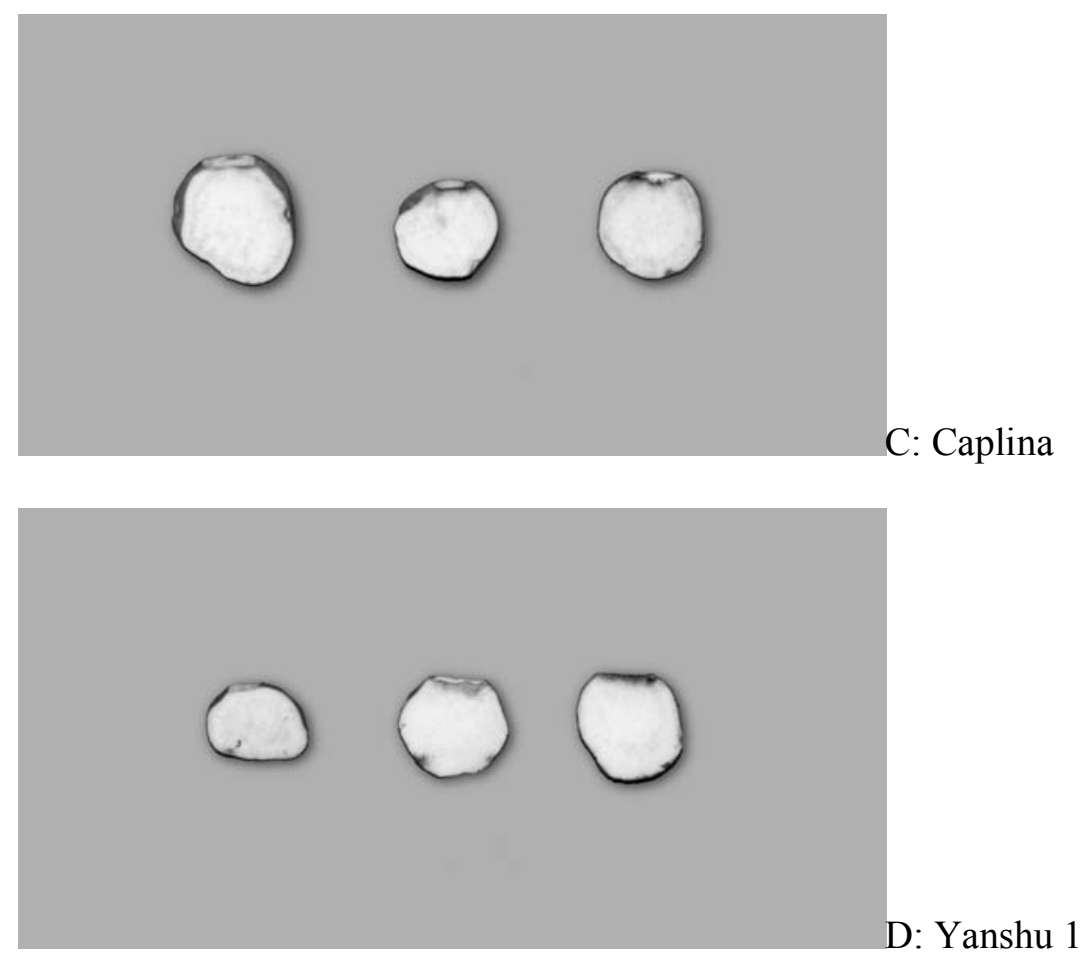

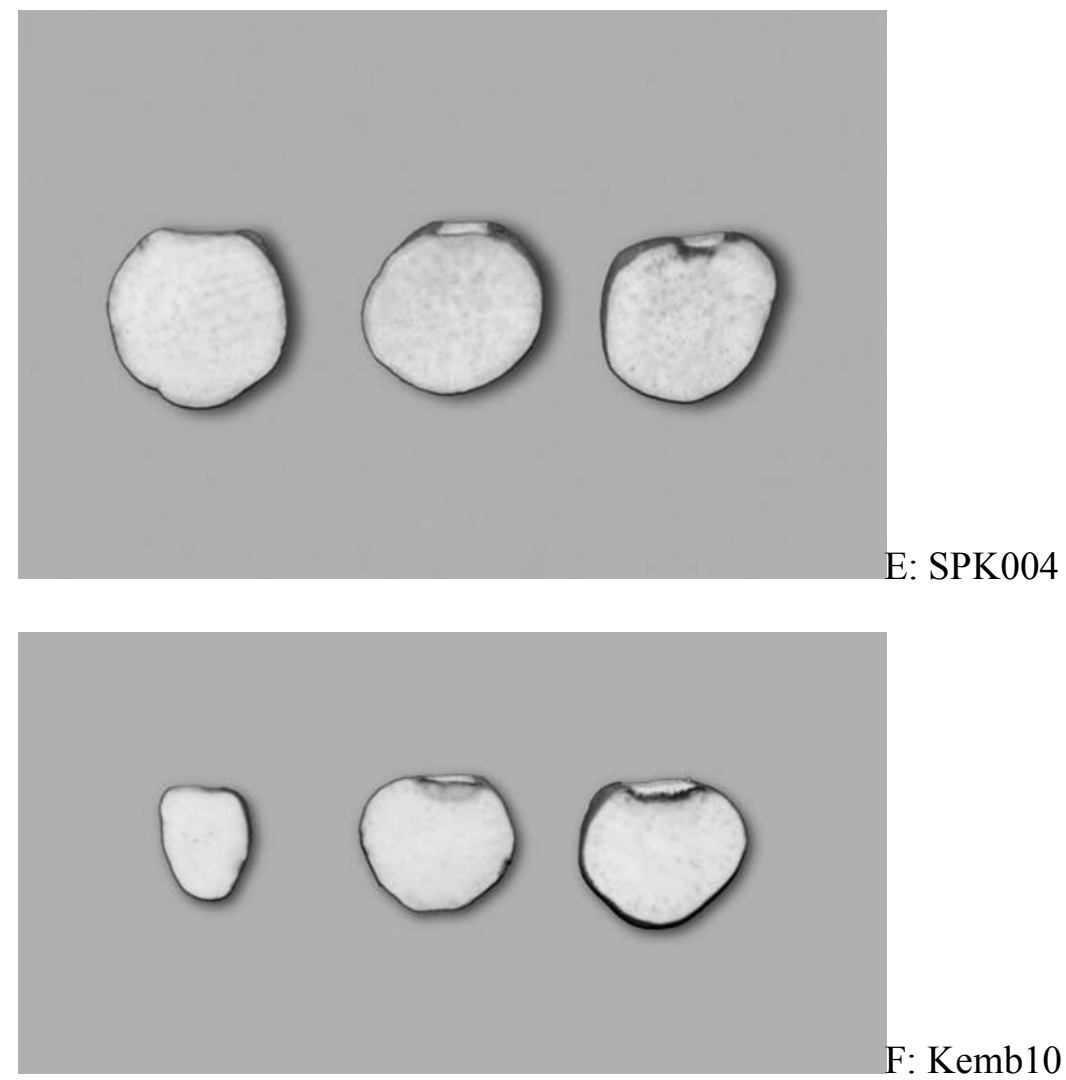

Figure 1 A, B, C, D, E, F. Variability in depth of desiccation depending on

cultivar and relative humidity. Transverse sections through wounded roots at 3 days after wounding. From left to right: 97\% RH, 65\% RH, 58\% RH. A Zapallo (Pumpkin); B BP1SP2;, C Caplina; D Yanshu; E SPK004; F Kemb 10

(Note: EPS Format also available) 

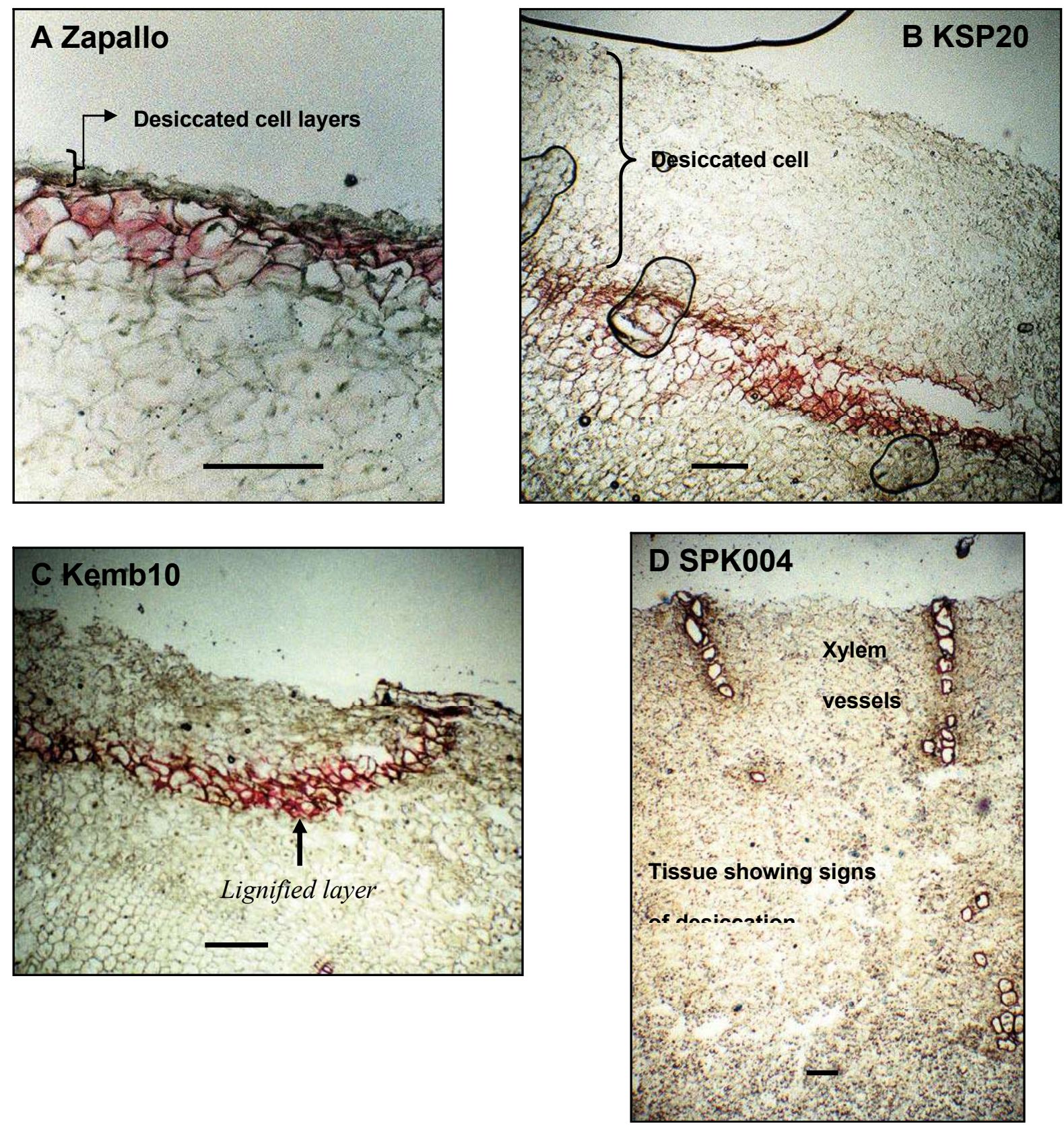

Figure 2 A, B C, D (Note: EPS Format also available)

\section{Sections through sweetpotato wounds at 6 days after wounding when the roots}

were kept at $71.1 \%$ RH and $T=20.9 \pm 1.6$. Sections were stained with

phloroglucinol (1\% in ethanol 95\%) as described in Material and Methods.

Magnification: $\mathrm{x} 40$ or $\mathrm{x} 100$. Bar $=100 \mu \mathrm{m}$.

A. Zapallo: thin desiccated cell layer (x 100)

B. KSP 20: 20 to 25 desiccated cell layers above patchy lignification (x40)

C. Kemb 10: onset of lignification (x40)

D. SPK 004: no lignified cell layers (x 40) 


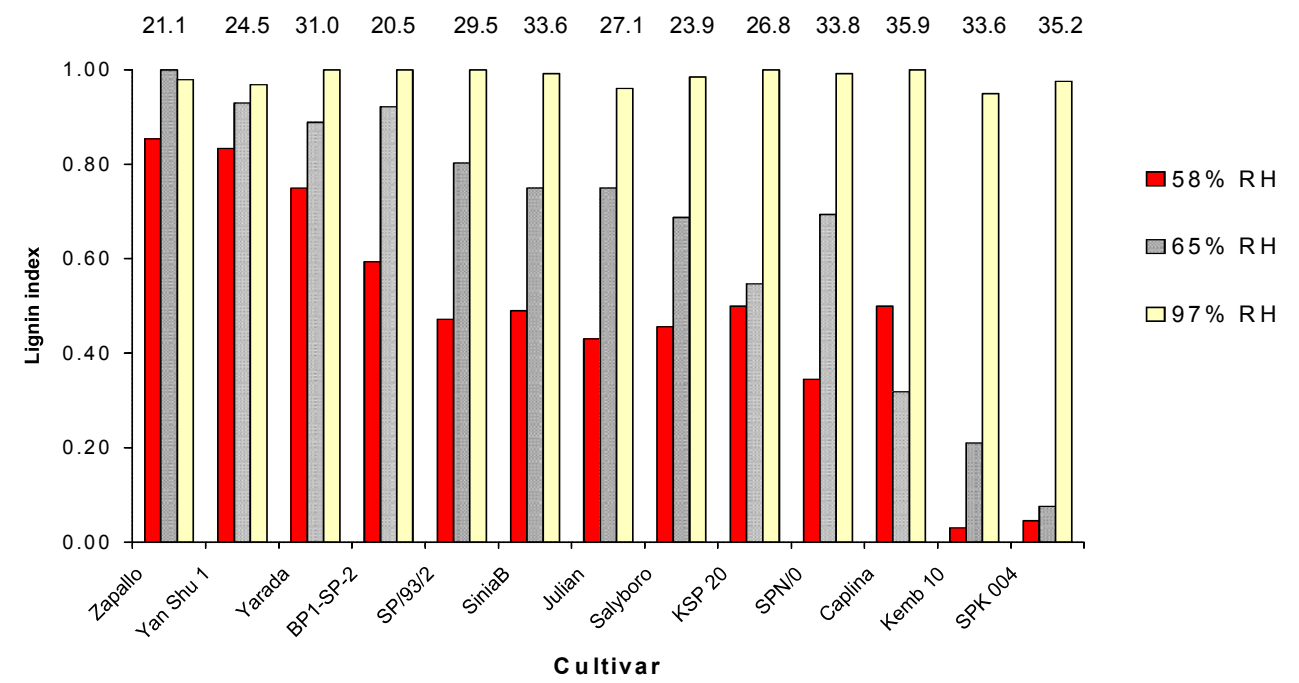

Dm content

Figure 3. The lignification index of 13 sweetpotato cultivars measured after healing at three relative humidities $(58 \%, 65 \%$ and $97 \%)$. Roots were obtained from Trial 8.. Experiment was set up in 3 replicates using at least 4 roots per rep, and analysis conducted at 3 and 6 days. As there was no significant effect of days the means of both data sets are displayed here. Cultivar root dry matter contents measured using 3 roots per cultivar are given at the top of the graph. 


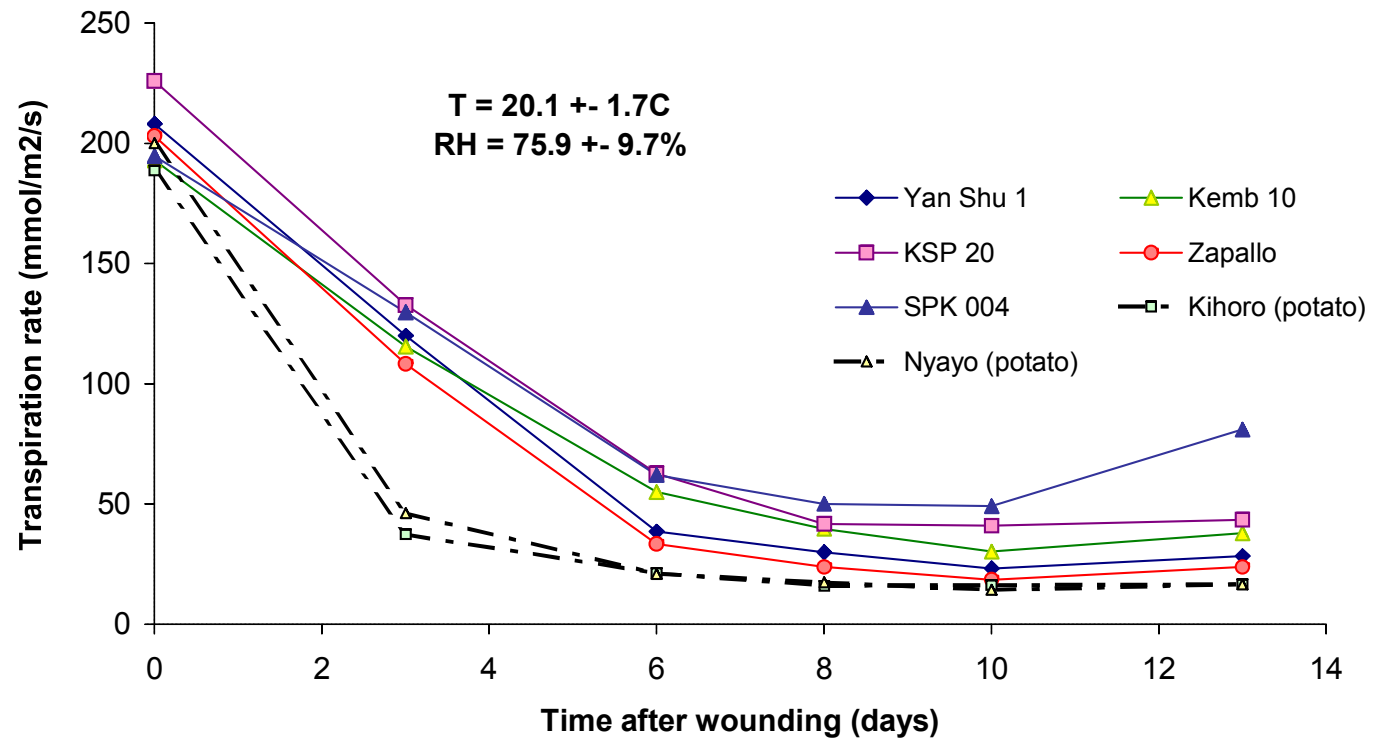

Figure 4 Transpiration rate through artificially inflicted wounds for 5 sweetpotato and 2 potato cultivars. Roots were obtained from trial 5. Each value is the mean of 5-10 measurements taken with a porometer at the wound site. Healing conditions $20^{\circ} \mathrm{C}, 76 \% \mathrm{RH}$. 

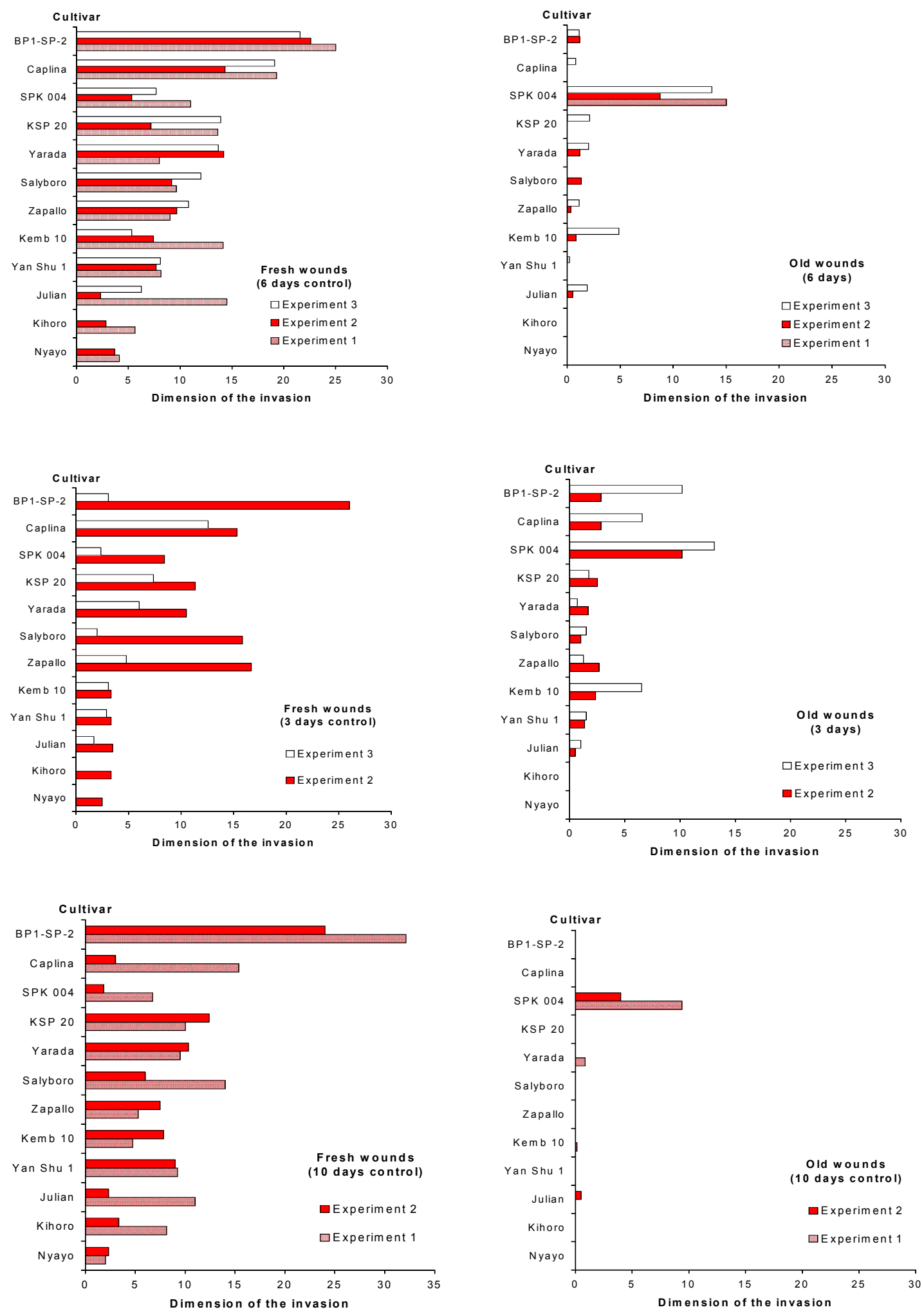

Figure 5 The dimensions of lesions of $R$. oryzae placed on 3, 6 or 10 day old

wounds. Roots were obtained from trials 4 and 5 Healing conditions $21^{\circ} \mathrm{C}$ and $71 \%$ and $76 \%$ RH respectively. Freshly cut wounds were used as controls. Mycelial plugs 
were placed on the wound and the roots were incubated for 2 days in plastic bags to maintain humidity $\left(\mathrm{RH}=95 \% ; \mathrm{T}=21-25^{\circ} \mathrm{C}\right)\left(\mathrm{LSD}_{3}\right.$ days $=6.96 ; \mathrm{LSD}_{6}$ days $=5.74$; $\left.\operatorname{LSD}_{10 \text { days }}=7.02\right)$. 


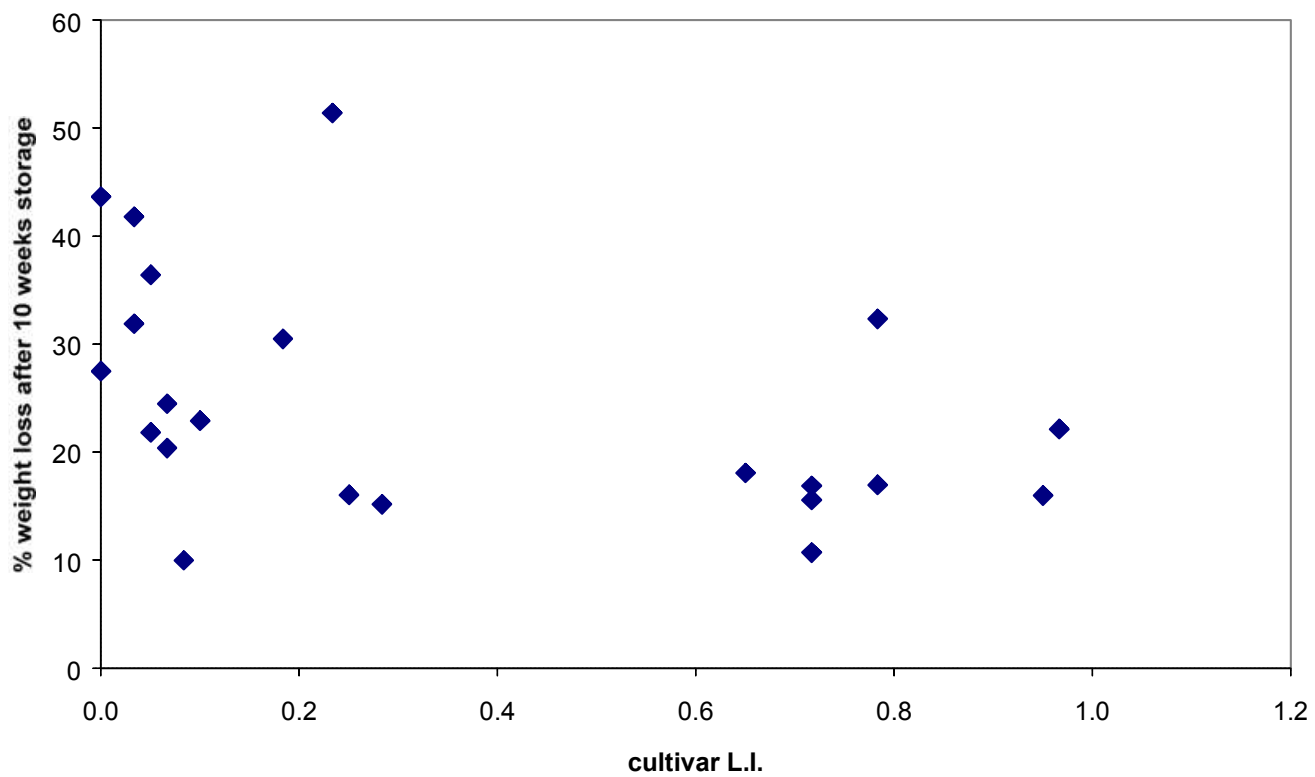

Figure 6:

The relationship between cultivar L.I. and \% root weight loss after 10 weeks of storage. Each point corresponds to a cultivar.

Roots were obtained from trial 3. L.I. was measured after curing at $65 \% \mathrm{RH}$ and $25^{\circ} \mathrm{C}$. Storage conditions were $19+/-1^{\circ} \mathrm{C}$ RH $60-70 \%$ the roots were kept in 10 reps, in cardboard boxes, each rep contained one root per cultivar). 

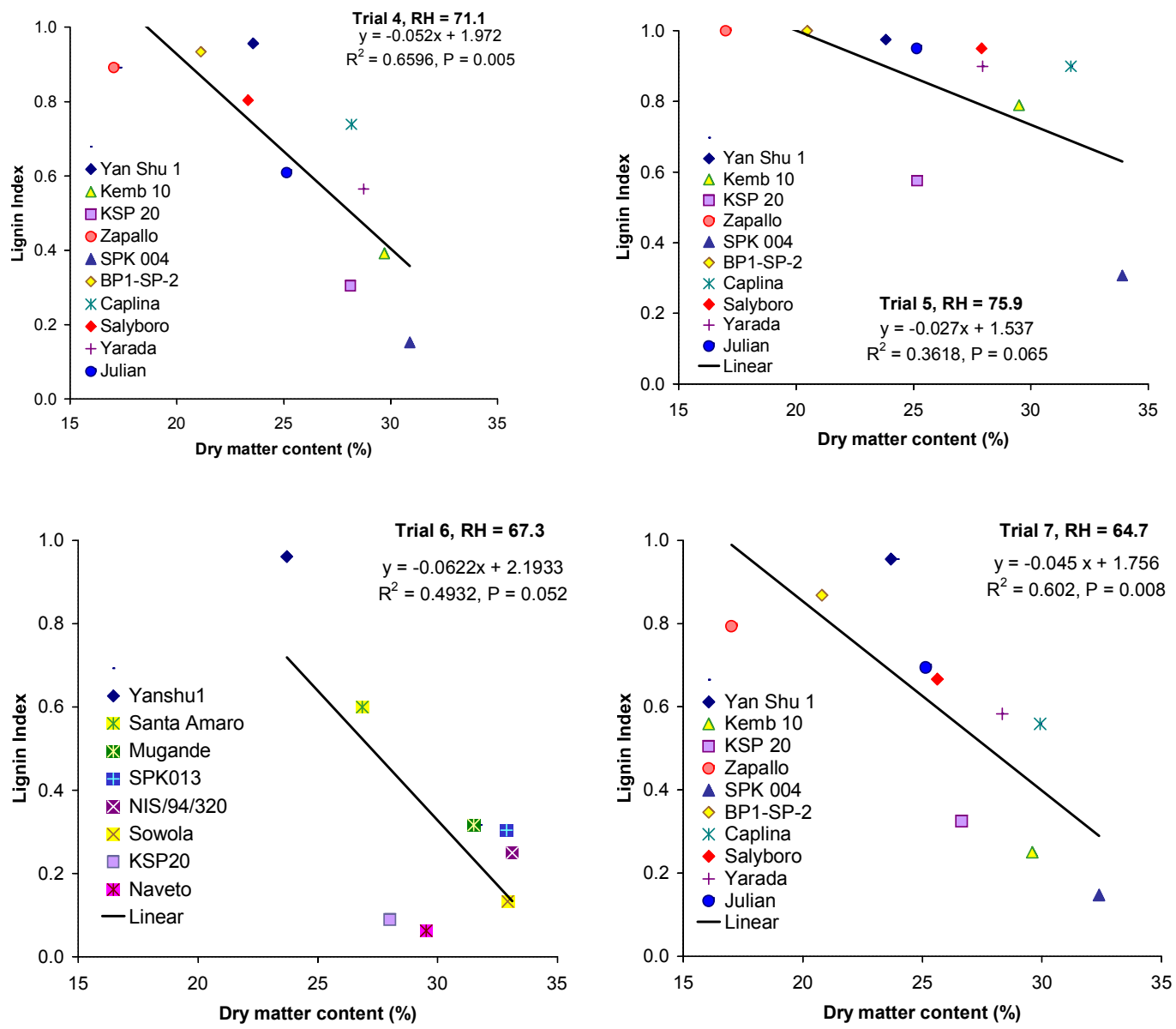

Figure 7: The relationship between cultivar DM content and the lignin index. Each point presents 1 cultivar. 